\title{
Correction to: Morphology of Drained Upland Depressions on the Des Moines Lobe of lowa
}

\author{
Samuel M. McDeid ${ }^{1}$ - David I. S. Green ${ }^{1}$ (D) - William G. Crumpton ${ }^{1}$
}

Published online: 2 September 2020

(C) () Springer Nature B.V. 20192020

\section{Correction to: Wetlands 2018 https://doi.org/10.1007/s13157-018-1108-4}

In the article by McDeid, S.M., Green, D.I.S. \& Crumpton, W.G. entitled Morphology of Drained Upland Depressions on the Des Moines Lobe of Iowa [Wetlands 2018, https://doi.org/10.1007/ s13157-018-1108-4], the following corrections have been added:

1. Pg. 7 Table 1 the following values have been changed:

a. DML-IA Areal Density: 6.3 to 7.3.

b. Algona Advance Areal Density: 12.9 to 13.3.

c. Moraines and Morainal Complexes Areal Density: 5.5 to 6.0 .

d. Algona Advance Mean $\mathrm{A}_{\max }: 0.72$ to 1.6 .

2. Pg. 7 second sentence, third paragraph under Spatial Distribution of Upland Depressions: 12.9 changed to 13.3.
3. Pg. 8 third sentence, first paragraph under Morphology of Upland Depressions: 369.3 changed to 3,692,503.

4. Pg. 8 second and third sentences, second paragraph under Morphology of Upland Depressions: changed to read "In general, depressions existing within the Algona Advance tend to be smaller, deeper, and have greater volumetric storage capacities than depressions existing within the Altamont Advance and the region's moraines and morainal complexes. Depressions within the Bemis Advance tend to be smaller, shallower, and have lower volumetric storage capacities than depressions in the other sub-regions."

Publisher's Note Springer Nature remains neutral with regard to jurisdictional claims in published maps and institutional affiliations.

The online version of the original article can be found at https://doi.org/ 10.1007/s13157-018-1108-4

David I. S. Green

dgreen1@iastate.edu

Samuel M. McDeid

samuel.mcdeid@googlemail.com

William G. Crumpton

crumpton@iastate.edu

1 Department of Ecology, Evolution, and Organismal Biology, Iowa State University, 251 Bessey Hall 2200 Osborn Dr.,

Ames, Iowa 50011, USA 